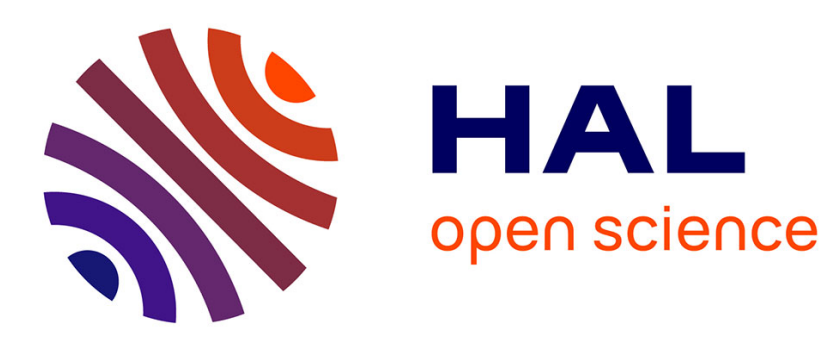

\title{
Ag-based electrocatalysts for ethylene epoxidation
}

B. Gilbert, T. Cavoue, M. Aouine, L. Burel, F.J. Cadete Santos Aires, A.

Caravaca, M. Rieu, J. P. Viricelle, S. Bruyere, D. Horwat, et al.

\section{To cite this version:}

B. Gilbert, T. Cavoue, M. Aouine, L. Burel, F.J. Cadete Santos Aires, et al.. Agbased electrocatalysts for ethylene epoxidation. Electrochimica Acta, 2021, 394, pp.139018. 10.1016/j.electacta.2021.139018 . hal-03402644

\section{HAL Id: hal-03402644 \\ https://hal.science/hal-03402644}

Submitted on 9 Nov 2021

HAL is a multi-disciplinary open access archive for the deposit and dissemination of scientific research documents, whether they are published or not. The documents may come from teaching and research institutions in France or abroad, or from public or private research centers.
L'archive ouverte pluridisciplinaire HAL, est destinée au dépôt et à la diffusion de documents scientifiques de niveau recherche, publiés ou non, émanant des établissements d'enseignement et de recherche français ou étrangers, des laboratoires publics ou privés. 


\section{Ag-based electrocatalysts for ethylene epoxidation}

B. Gilbert ${ }^{1}$, T. Cavoue ${ }^{2}$, M. Aouine ${ }^{2}$, L. Burel ${ }^{2}$, F.J. Cadete Santos Aires ${ }^{2}$, A. Caravaca ${ }^{2}$, M. Rieu ,

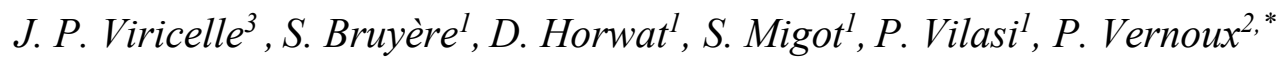

${ }^{1}$ Université de Lorraine, CNRS, IJL, F-54000 Nancy, France

${ }^{2}$ Université de Lyon, Institut de Recherches sur la Catalyse et l'Environnement de Lyon, UMR 5256, CNRS, Université Claude Bernard Lyon 1, 2 avenue A. Einstein, F-69626 Villeurbanne, France.

${ }^{3}$ Mines Saint-Etienne, Univ Lyon, CNRS, UMR 5307 LGF, Centre SPIN, F -42023 Saint-Etienne, France

*Corresponding author: philippe.vernoux@ircelyon.univ-lyon1.fr 


\begin{abstract}
Ethylene oxide (EO) is industrially produced by epoxidation of ethylene on Ag-based heterogeneous catalysts. Electrophilic oxygen species are assumed to be active key species in the EO production. This study explores the possibility to electrochemically produced these oxygen species in a solid oxide electrochemical cell. Two series of Ag based cermet electrodes were prepared either with Yttria Stabilized Zirconia (YSZ), a pure oxygen ionic conductor, or with Gadolinia-Doped Ceria (GDC), a mixed ionic and electronic conductor. Ag/YSZ cermet layers were deposited on planar and tubular YSZ dense substrates by using a conventional chemical method while Ag/GDC cermets were coated on GDC dense pellets by reactive magnetron sputtering. We evidenced a self-redispersion of Ag in the ethylene/oxygen mixture in Ag/YSZ cermet layers leading to the formation of small Ag clusters in close interaction with YSZ which are selective for epoxidation. However, the sintering process of these small Ag clusters is too fast even at $260^{\circ} \mathrm{C}$ to maintain the EO selectivity. On the other hand, the selectivity towards $\mathrm{EO}$ and the ethylene conversion of $\mathrm{Ag} / \mathrm{GDC}$ cermet coatings were found to linearly increase with the applied current, demonstrating for the first time, the direct electrooxidation of ethylene into EO.
\end{abstract}

Keywords: ethylene epoxidation, Ag, ethylene oxide, oxide ions, electrooxidation, reactive magnetron sputtering, YSZ, GDC. 


\section{Introduction}

Ethylene oxide (EO) is nowadays a chemical intermediate of paramount importance. As one of the highest volume petrochemicals, it serves as a precursor for the further production of added value molecules, including plastics, polyester and ethylene glycol [1-3]. EO is industrially produced by the partial oxidation (epoxidation) of ethylene with air (or oxygen) on $\mathrm{Ag} / \alpha-\mathrm{Al}_{2} \mathrm{O}_{3}$ catalysts at low reaction temperatures (around $220^{\circ} \mathrm{C}$ ) and high pressures $(10-30$ bar) [3,4]. Silver is the only one known active heterogeneous catalyst for the epoxidation of ethylene. The epoxidation is in competition with the combustion side reactions of both ethylene and $\mathrm{EO}$, leading to the production of $\mathrm{CO}_{2}$ and $\mathrm{H}_{2} \mathrm{O}$. $\alpha$-alumina is commonly selected as a support since this oxide exhibits a low specific surface area (below $10 \mathrm{~m}^{2} \mathrm{~g}^{-1}$ ) and a rather small surface concentration of $\mathrm{OH}$ groups, in

order to avoid undesired reactions [5]. In the absence of any chemical promoters, the selectivity towards $\mathrm{EO}$ is in the range of $35-50 \%$ at $220^{\circ} \mathrm{C}$ depending on the $\mathrm{O}_{2} / \mathrm{C}_{2} \mathrm{H}_{4}$ ratios $[6,7]$. Few ppm of chlorinated hydrocarbons (e.g. ethyl chloride or vinyl chloride) are introduced in the gas phase to improve the selectivity to values $\sim 90 \%$ at around $10 \%$ ethylene conversion [3]. Despite intensive research efforts, the reaction mechanism and the exact role of these promoters are still unclear [3]. One of the most accepted ideas is that $\mathrm{Cl}^{-}$anions weaken the $\mathrm{Ag}-\mathrm{O}$ interaction, leading to the production of reactive electrophilic oxygen species [1], which are assumed to be active in the EO production $[3,8]$. Such active oxygen species can also be electrochemically produced by using an oxygen ionic conductor as a support [9]. Pioneer studies [10-13] on Ag interfaced on Yttria Stabilized Zirconia (YSZ), an oxygen ionic conductor, evidenced that electrochemically produced electrophilic oxygen species on Ag can act as electronic promoters to enhance the ethylene conversion [9]. The catalytic rate increase was found to be much higher than that predicted by the Faraday law (Faradaic efficiencies of around 3000\% [13]) as the enhancement mainly depends on the lifetime of the ionic oxygen promoters on the Ag surface according to the concept 
of Electrochemical Promotion of Catalysis (EPOC) [9]. The ionic promoters weaken Ag-O bonds but strengthen Ag-EO bonds rendered $\mathrm{EO}$ more susceptible to further oxidation towards $\mathrm{CO}_{2}$. All in all, these EPOC studies concluded that the ethylene conversion on $\mathrm{Ag}$ films deposited on an $\mathrm{O}^{2-}$ conducting solid electrolyte can be significantly electrochemically promoted, but not the EO selectivity. All these studies dealt with pure Ag coatings which were poorly dispersed (micrometric Ag agglomerates) with a weak interaction between Ag and the solid electrolyte. This study proposes to investigate $\mathrm{Ag}$ based cermet coatings in which $\mathrm{Ag}$ is intimately mixed with the oxygen ionic conductor aiming to boost electrochemical performances and then the migration rate of active electrophilic oxygen species from the solid electrolyte toward Ag active sites.

We have prepared two kinds of Ag/ionic conductor cermet coatings. The first series involved YSZ, a pure oxygen ionic conductor, while the second used Gadolinia-Doped Ceria (GDC), a mixed ionic and electronic conductor (MIEC). Ag/YSZ cermet layers were deposited on planar and tubular YSZ dense substrates by using a conventional chemical method. On the other hand, $\mathrm{Ag} / \mathrm{GDC}$ cermets were coated on GDC dense pellets by reactive magnetron sputtering. The nanostructure of these layers and in particular the local arrangement between Ag and ionically conducting grains were ex-situ characterized by SEM, TEM, XPS, XRD and SIMS as well as by in-situ Environmental-SEM (ESEM) and TEM (ETEM). We have explored the catalytic activity for ethylene epoxidation of these cermet coatings with and without electrical polarisation at atmospheric pressure between 220 and $320^{\circ} \mathrm{C}$ in an ethylene/oxygen feed.

\section{Experimental}

\subsection{Preparation of $\mathrm{Ag} / \mathrm{YSZ}$ cermet coatings}


YSZ dense disks (18.7 $\mathrm{mm}$ diameter and $1 \mathrm{~mm}$ thick) and bottom-closed tubes (300 $\mathrm{mm}$ length, 22 $\mathrm{mm}$ external diameter, $1 \mathrm{~mm}$ thick) were prepared by sintering a commercial YSZ powder (Tosoh, $\mathrm{ZrO}_{2}-8 \mathrm{~mol} \% \mathrm{Y}_{2} \mathrm{O}_{3}$ ) at $1350{ }^{\circ} \mathrm{C}$ for $2 \mathrm{~h}$ in ambient air (densification higher than $98 \%$ ). $\mathrm{Ag} / \mathrm{YSZ}$ cermet coatings were prepared from a commercial Ag organic ink (Metalor ${ }^{\circledR}$ HPS-FG32) and a Tosoh YSZ powder (mean grain size $=40 \mathrm{~nm}$ and specific surface area $=16 \mathrm{~m}^{2} \mathrm{~g}^{-1}$ ) according to a previously reported procedure [14]. The Ag ink was mixed with the YSZ powder in ethanol, deposited with a brush on one side of a YSZ disk (electrode area $=2.7 \mathrm{~cm}^{2}$ ) and calcined at $600{ }^{\circ} \mathrm{C}$ for $2 \mathrm{~h}$ in static air (heating ramp of $\left.2{ }^{\circ} \mathrm{C} \min ^{-1}\right)$. The cermet loading was $\sim 10 \mathrm{mg}\left(\sim 3.7 \mathrm{mg} . \mathrm{cm}^{-}\right.$

${ }^{2}$ ), with an $\mathrm{Ag} / \mathrm{YSZ}$ weight $\%$ ratio of $75 / 25$ to ensure the Ag percolation. The same coating was also deposited on the external side of a YSZ dense gauge (Fig. S1). An external area of $14 \mathrm{~cm}^{2}$ was covered with $\sim 51 \mathrm{mg}$ of the $\mathrm{Ag} / \mathrm{YSZ}$ cermet $\left(\sim 3.6 \mathrm{mg} . \mathrm{cm}^{-2}, \mathrm{Ag} / \mathrm{YSZ}\right.$ weight ratio $\left.=75 / 25\right)$. For comparison, we have also prepared a pure Ag coating $\left(\sim 20 \mathrm{mg}\right.$, i.e. $\left.\sim 7.4 \mathrm{mg} . \mathrm{cm}^{-2}\right)$ from the commercial Ag ink with the same calcination procedure.

For electrocatalytic experiments, a symmetrical counter-electrode (CE) made of Au was deposited, as for $\mathrm{Ag} / \mathrm{GDC}$ layers, on the other side of the planar buttom cells (YSZ disks) by magnetron sputtering. On the other hand, a symmetrical Pt electrode, always exposed to ambient air, was deposited from a Pt paste (Engelhard-Clal 6926) annealed at $800^{\circ} \mathrm{C}$ for $2 \mathrm{~h}$ in air in the inner side of the YSZ tubular YSZ cell as described in ref. [15] and in Fig. S1.

\subsection{Preparation of $\mathrm{Ag} / \mathrm{GDC}$ cermet coatings}

$\mathrm{Ag} / \mathrm{GDC}$ cermet coatings were prepared by reactive magnetron sputtering (Fig. S2a) without thermal assistance using reactive magnetron co-sputtering of a Ce-Gd alloyed target containing 20 at $\% \mathrm{Gd}$ and a silver target (target purities $99.99 \%$ ) in an $\mathrm{Ar} / \mathrm{O}_{2}$ reactive gas mixture. Catalysts 
were first deposited on (001) silicon pieces for characterization purposes. The synthesis parameters were adjusted to reach a $\mathrm{Ag} /(\mathrm{Ag}+\mathrm{Ce}+\mathrm{Gd})$ mass ratio close to $71 \%$, as measured by $\mathrm{EDS}$, to have an electronic percolation of Ag. Prior to deposition, the deposition chamber was evacuated thanks to a primary mechanical pump and a turbomolecular pump allowing a base vacuum of $10^{-4} \mathrm{~Pa}$. The target-to-substrate distance was fixed at $5 \mathrm{~cm}$. The argon and $\mathrm{O}_{2}$ gas flow rates were fixed at 83 and $2.5 \mathrm{sccm}$, respectively, and the pumping speed was adjusted to $20 \mathrm{rpm}$ in order to obtain a total working pressure of $4 \mathrm{~Pa}$. The Ce-Gd target was sputtered by applying a discharge current of 0.8 A using a pulsed direct current Pinnacle $+5 \mathrm{~kW}$ Advanced Energy supply operated at a frequency of $50 \mathrm{kHz}$ and an OFF time of $4 \mu \mathrm{s}$, while the $\mathrm{Ag}$ target was sputtered by applying a discharge current of $70 \mathrm{~mA}$ with a direct current MDX 500 Advanced Energy supply. The substrates-holder was put in rotation and all the substrates were positioned on the substrates-holder at the circumference facing the targets axis. This allows the simultaneous deposition of films with a reproducible and homogeneous chemical composition [16].

Aiming to perform electrocatalytic experiments on ethylene epoxidation, solid oxide buttom cells were prepared from GDC (containing $20 \%$ mol. of $\mathrm{Gd}_{2} \mathrm{O}_{3}$ ) dense membranes (18.7 mm diameter, $1 \mathrm{~mm}$ thickness), a well-known oxygen ionic conductor [17]. Ag/GDC cermet coatings were deposited as working electrode (W) on one side of GDC membranes by reactive sputtering as described before, followed by a calcination step at $350^{\circ} \mathrm{C}$ for $2 \mathrm{~h}$. A symmetrical counter-electrode (CE) made of Au was deposited on the other side of the disks by magnetron sputtering. Gold was selected due to its negligible catalytic activity for ethylene epoxidation, as verified via blank experiments under our experimental reaction conditions. The Ag/GDC loading was measured to be $0.16 \mathrm{mg} . \mathrm{cm}^{-2}$, i.e. a $\mathrm{Ag}$ concentration of $0.11 \mathrm{mg} \cdot \mathrm{cm}^{-2}$. 


\subsection{Characterizations of the electrocatalytic coatings}

The structure of all coatings was analyzed by X-ray diffraction (XRD) analysis using a D8 Advance Bruker diffractometer using the $\mathrm{Cu}-\mathrm{K} \alpha_{1}$ radiation in $\theta / 2 \theta$ configuration.

Ag/GDC coatings were deeply characterized by the following techniques. A Secondary ion mass spectrometry (SIMS) was used to collect depth profile chemical analysis using a Cameca IMS 7F spectrometer equipped with a $\mathrm{Cs}^{+}$ion source. In addition, the core level electronic structure was measured using X-ray photoelectron spectroscopy (XPS) at the C 1s and Ag 3d levels. The surface morphology of the porous films was analyzed before and after annealing using a Zeiss Gemini 500 scanning electron microscope operated in secondary electron mode under $2 \mathrm{kV}$ accelerating voltage. A video has also been recorded using a Quanta 200 ESEM FEG environmental scanning electron microscope during a thermal ramp at $12{ }^{\circ} \mathrm{C} / \mathrm{min}$ from room temperature up to $350{ }^{\circ} \mathrm{C}$ and a plateau of $7200 \mathrm{~s}$ at $350{ }^{\circ} \mathrm{C}$ in $120 \mathrm{~Pa}$ of air. The cross-section morphology and chemical contrast were observed after the thermal ramp and plateau using the same microscope operated at $5 \mathrm{kV}$ in backscattered electron detection mode. Details of the structure, microstructure and $\mathrm{Ce}, \mathrm{Ag}$ and $\mathrm{O}$ composition maps were collected on a Ag/GDC sample after catalytic test using cold FEG JEOL ARM200 high resolution transmission electron microscope. Cross-section TEM samples of films were prepared using MEB-FIB Helios NanoLab 600i of FEI company.

Ag/YSZ cermet layers were observed ex-situ by Transmission Electron Microscopy (TEM) using a JEOL 2010 microscope operated at $200 \mathrm{kV}$ and equipped with an UHR pole-piece (point resolution: $0.196 \mathrm{~nm}$ ) and an energy-dispersive X-ray (EDX) Spectrometer Pentafet-LinK from Oxford Instruments ${ }^{\mathrm{TM}}$ ). The catalyst coatings were scratched and dispersed in dry ethanol using an ultrasound bath. One drop of solution was then deposited on a copper grid for TEM measurements. An Environmental Transmission Electron Microscope (ETEM, Titan G2 80-300 kV from FEI ${ }^{\mathrm{TM}}$ ) 
was used to observe in situ the nanostructure of the Ag/YSZ cermet under the reaction conditions typical for ethylene epoxidation. First, the sample was heated up to $300{ }^{\circ} \mathrm{C}$ in $\mathrm{N}_{2}(4 \mathrm{mbar})$. Then, the reaction mixture $\left(3.8 \% \mathrm{C}_{2} \mathrm{H}_{4} / 1.1 \% \mathrm{O}_{2}\right)$ was introduced. Images were captured every 20 seconds for $1 \mathrm{~h}$ and 45 minutes. This ETEM microscope was equipped with an objective lens aberration corrector (measured resolution : $0.08 \mathrm{~nm}$ under $\mathrm{UHV} ; 0.09 \mathrm{~nm}$ under $0.5 \mathrm{mbar} \mathrm{N}_{2}$ ), an energy-dispersive X-ray EDX spectrometer (SDD X-Max ${ }^{\mathrm{N}} 80$ from Oxford Instruments ${ }^{\mathrm{TM}}$ ), a OneView $^{\circledR}$ high speed (capable of acquiring 100 frames per second at $2 \mathrm{kx} 2 \mathrm{k}$ ) and high dynamic range (beyond 16-bits) camera. The scanning transmission electron microscopy (STEM) mode was also used in association with an annular-dark field (ADF) detector for atomic number (Z) contrast imaging. The sample was deposited on titania grids covered with a 200 silica film and placed into a Gatan $^{\mathrm{TM}}$ furnace-type holder. The ETEM was operated at 80 and $300 \mathrm{kV}$ accelerating voltages to evaluate the effect of the electron beam energy.

\subsection{Electrocatalytic activity measurements}

The electrocatalytic activity of buttom planar solid oxide cells was measured in a U-shaped quartz reactor, described in reference [18], operating under continuous flowing conditions at atmospheric pressure. Catalytic tests were performed with two reactive mixtures: $3.8 \% \mathrm{C}_{2} \mathrm{H}_{4} / 1.1 \% \mathrm{O}_{2}$ (ethylene rich, $\mathrm{O}_{2} / \mathrm{C}_{2} \mathrm{H}_{4}=0.29$ ) and $1 \% \mathrm{C}_{2} \mathrm{H}_{4} / 2 \% \mathrm{O}_{2}$ (oxygen rich, $\mathrm{O}_{2} / \mathrm{C}_{2} \mathrm{H}_{4}=2$ ). The overall flow was $3 \mathrm{~L} \mathrm{~h}^{-}$ 1.

The catalytic properties of Ag/YSZ cermet coatings were evaluated in ethylene rich conditions at three different temperatures $\left(260,300\right.$ and $\left.320^{\circ} \mathrm{C}\right)$ by using a new sample for each test. The tubular solid oxide cell was inserted into a quartz tube to ensure the gas circulation (Fig. S1). The flow passed between the YSZ tube and the quartz tube (very low gap volume of $8 \mathrm{~cm}^{3}$ ) and licked the $\mathrm{Ag} / \mathrm{YSZ}$ cermet layer as described in ref. [19]. Torr-Seal adhesive (Varian Vacuum Products) was 
applied between the top of YSZ and quartz tubes in order to insure the sealing. This extremity part of the reactor was kept out of the furnace. The $\mathrm{Ag} / \mathrm{YSZ}$ cermet coating was exposed to the reactive mixture (ethylene rich conditions) whereas the symmetrical Pt counter-electrode was under air.

The reactants and products were analyzed by an on-line micro gas-chromatograph ( $\mu \mathrm{GC}-\mathrm{R} 3000$, SRA) composed of a BF PPU 8m/PPQ 1m column ( $\mathrm{CO}_{2}$ analysis) and a VAR PLOT Q 8m column (EO and acetaldehyde analysis). The detection limit for EO analysis was $\sim 2 \mathrm{ppm}$. In addition, an infrared $\mathrm{CO}_{2}$ analyzer (HORIBA VA-3000) was used for faster resolution $\mathrm{CO}_{2}$ analysis. The concentration of acetaldehyde was found to be negligible for all measurements. $\mathrm{CO}_{2}$ and $\mathrm{EO}$ were the only two detected products. Working (W) and counter electrodes (CE) of the solid oxide cells were connected to a potentiostat/galvanostat PGZ402 (Radiometer Analytical).

Electrocatalytic experiments were mainly performed on Ag-GDC/GDC planar solid oxide cells. Pulses of current intensity were applied for $1 \mathrm{~h}$ starting from $100 \mu \mathrm{A}$ up to a maximum of $1000 \mu \mathrm{A}$ with an increment of $100 \mu \mathrm{A}$, within the limit of a maximum cell voltage of $4 \mathrm{~V}$, corresponding to less than $1.8 \mathrm{~V}$ ohmic free voltage. The minimum value of the ohmic drop was found to be $2.3 \mathrm{~V}$ at $300^{\circ} \mathrm{C}$ in ethylene rich conditions. Between each current pulse, the electrocatalyst was maintained at OCV (Open Circuit Voltage) for $1 \mathrm{~h}$. The gains of EO selectivity and ethylene consumption rate upon current imposition were calculated according to equations 1 and 2.

EO selectivity gain $(\%)=100 \times\left(\mathrm{S}_{\mathrm{EO}, \mathrm{p}}-\mathrm{S}_{\mathrm{EO}, \mathrm{O}}\right) / \mathrm{S}_{\mathrm{EO}, \mathrm{O}}$

with $\mathrm{S}_{\mathrm{EO}, \mathrm{O}}$ and $\mathrm{S}_{\mathrm{EO}, \mathrm{p}}$ are the EO selectivity at $\mathrm{OCV}$ and under polarization (promoted state), respectively.

Ethylene consumption rate gain $(\%)=100 \mathrm{x}(\mathrm{rp}-\mathrm{ro}) / \mathrm{ro}$ 
with ro and rp are the ethylene consumption rate at OCV and under polarization (promoted state), respectively. The Faradaic efficiency corresponding to the production of EO upon polarization was calculated according to this equation:

$\mathrm{FE}_{\mathrm{Eo}}(\%)=100 \times\left[\left(\mathrm{r}_{\mathrm{EO}, \mathrm{p}}-\mathrm{r}_{\mathrm{EO}, \mathrm{o}}\right) /(\mathrm{I} / 2 \mathrm{~F})\right]$

Where $\mathrm{r}_{\mathrm{EO}, \mathrm{p}}$ and $\mathrm{r}_{\mathrm{EO}, \mathrm{o}}$ are the production rates of $\mathrm{EO}$ expressed in $\mathrm{mol} \mathrm{O} / \mathrm{s}$ under polarization (promoted state) and at OCV, I the applied current (A) and F the Faraday constant ( $\mathrm{F}=96500 \mathrm{C})$. We have considered 2 electrons exchanged in the Faraday law according to the electrochemical oxidation of $\mathrm{C}_{2} \mathrm{H}_{4}$ into $\mathrm{EO}(2)$.

$\mathrm{C}_{2} \mathrm{H}_{4}(\mathrm{~g})+\mathrm{O}^{2-}(\mathrm{GDC}) \rightarrow \mathrm{C}_{2} \mathrm{H}_{4} \mathrm{O}(\mathrm{g})+2 \mathrm{e}^{-}(\mathrm{Ag})$

\section{Results and discussion}

\subsection{Characterizations and catalytic activity of $\mathrm{Ag} / \mathrm{YSZ}$ cermet coatings}

$\mathrm{Ag} / \mathrm{YSZ}$ cermet layers, of around $3 \mu \mathrm{m}$ thick, are composed of micrometric Ag agglomerates surrounded by YSZ grains (Fig. S3 and Fig. S4a). Comparatively, the morphology of pure Ag films (Fig. S3) are denser and thicker (ca. $10 \mu \mathrm{m}$ ), as previously observed [20]. These latter coatings exhibit a poor catalytic performance (not shown here), with ethylene conversions lower than 0.01 $\%$ at $300{ }^{\circ} \mathrm{C}$ and a null production of the product of interest (EO). This indicates that large micrometric Ag agglomerates are not active for ethylene epoxidation. In addition, the application of positive currents $( \pm 500 \mu \mathrm{A})$ at $300^{\circ} \mathrm{C}$ had no impact on the catalytic performances. On the other hand, Ag/YSZ cermet layers exhibit improved catalytic performances (Fig. 1). We have recorded the time evolution of the EO selectivity and the intrinsic ethylene consumption rate at three different reaction temperatures $\left(260,300\right.$ and $\left.320^{\circ} \mathrm{C}\right)$. Whatever the temperature, the catalytic 
activity is initially negligible but increases with time to reach a steady state after ca. $6 \mathrm{~h}$ on stream. The EO selectivity follows an opposite trend, passing trough a maximum, to finally decrease and stabilize at a low value. As expected, the steady state value of the EO selectivity decreases with the temperature while that of the ethylene consumption rate increases. This is due to the temperature activation of the complete oxidation of ethylene to $\mathrm{CO}_{2}$ [21]. However, the most interesting part of these experiments was observed before reaching the stabilization of the catalytic activity. For instance, at $300{ }^{\circ} \mathrm{C}$, after an induction time of ca. $25 \mathrm{~min}$, the ethylene consumption rate gradually increases while the EO selectivity reaches an optimum close to $40 \%$ after 50 min on stream. After this maximum, the selectivity gradually decreases down to $20 \%$ and then abruptly drops after $3 \mathrm{~h}$ on stream, coinciding with a sudden increase of the ethylene consumption rate. A similar trend was observed at $320{ }^{\circ} \mathrm{C}$ but the process was much faster as the optimum of selectivity (26\%) was obtained after only few min on stream. At $260^{\circ} \mathrm{C}$, the time variation of the selectivity was similar to that at $300^{\circ} \mathrm{C}$, except the decay after $2.5 \mathrm{~h}$ on stream which was more gradual like the concomitant increase of the catalytic rate. All these results emphasize a temperature dependent operando rearrangement of the $\mathrm{Ag} / \mathrm{YSZ}$ cermet coating. At $300^{\circ} \mathrm{C}$, an intermediate "selective" state of the electrocatalyst can be maintained for ca. $2.2 \mathrm{~h}$ with selectivity higher than $20 \%$.

The catalytic properties of the tubular Ag/YSZ cell were also investigated at $300{ }^{\circ} \mathrm{C}$ in ethylene rich conditions (Fig. 2). We observed a similar dynamic process on stream of the Ag/YSZ cermet. After an induction time of $\sim 25$ minutes, the EO selectivity increases progressively reaching an optimum value of $55 \%$ after $2.5 \mathrm{~h}$ on stream, following by a slow decay down to $48 \%$ after 8.8 h. During the same period, the ethylene consumption gradually increases up to $0.07 \mathrm{mmol} \cdot \mathrm{g}^{-1} \cdot \mathrm{h}^{-1}$. After $8.8 \mathrm{~h}$, a drastic drop of EO selectivity takes place, together with a fast increase of $\mathrm{CO}_{2}$ production and of the ethylene consumption rate. The system reaches the "steady-state" after $12.8 \mathrm{~h}$ on stream, corresponding to an EO selectivity of $9.2 \%$ and a catalytic rate of $0.16 \mathrm{mmol.g}^{-}$ 
${ }^{1} \cdot \mathrm{h}^{-1}$. These catalytic properties are similar to those of the planar Ag/YSZ cells, except the duration of the intermediate "selective" state which can be extended for more than $7 \mathrm{~h}$. It is worth noting that the stabilized intrinsic catalytic rate at $300^{\circ} \mathrm{C}$ of the tubular cell is 3.3 times lower than that of the planar samples, probably explaining the slightly higher optimal EO selectivity values (55\% instead of $37 \%$ ). Hence, under the same gas composition and total flow, a higher amount of $\mathrm{Ag} / \mathrm{YSZ}$ cermet (around 5 times) has a larger capacity to produce active sites for ethylene epoxidation, enhancing the durability of the intermediate "selective" state.

Representative TEM images of Ag/YSZ cermet coatings after the catalytic experiments (Fig. S4 b to d) evidence the on-stream production of Ag nanoparticles supported on YSZ grains. To get more insights, a $\mathrm{Ag} / \mathrm{YSZ}$ cermet layer was exposed to the reactive mixture at $300^{\circ} \mathrm{C}$ for only $45 \mathrm{~min}$, period required to reach the optimal EO selectivity (Figs. 1 and 2). After a fast cooling in He, the sample was analyzed ex-situ by high-resolution STEM (Fig. 3). We found that the surface of YSZ was covered with Ag nanoparticles (Fig. 3a-b). Very small Ag clusters $(\sim 2-5 \mathrm{~nm})$ in strong interaction with YSZ can be clearly detected (Fig. 3c-d). These results suggest the operando formation of Ag clusters growing epitaxially on YSZ crystallites. However, the YSZ surface is rapidly fully covered by Ag clusters (Fig. 3a-b) which start to coalesce for producing larger Ag nanoparticles, mainly active for ethylene combustion. 

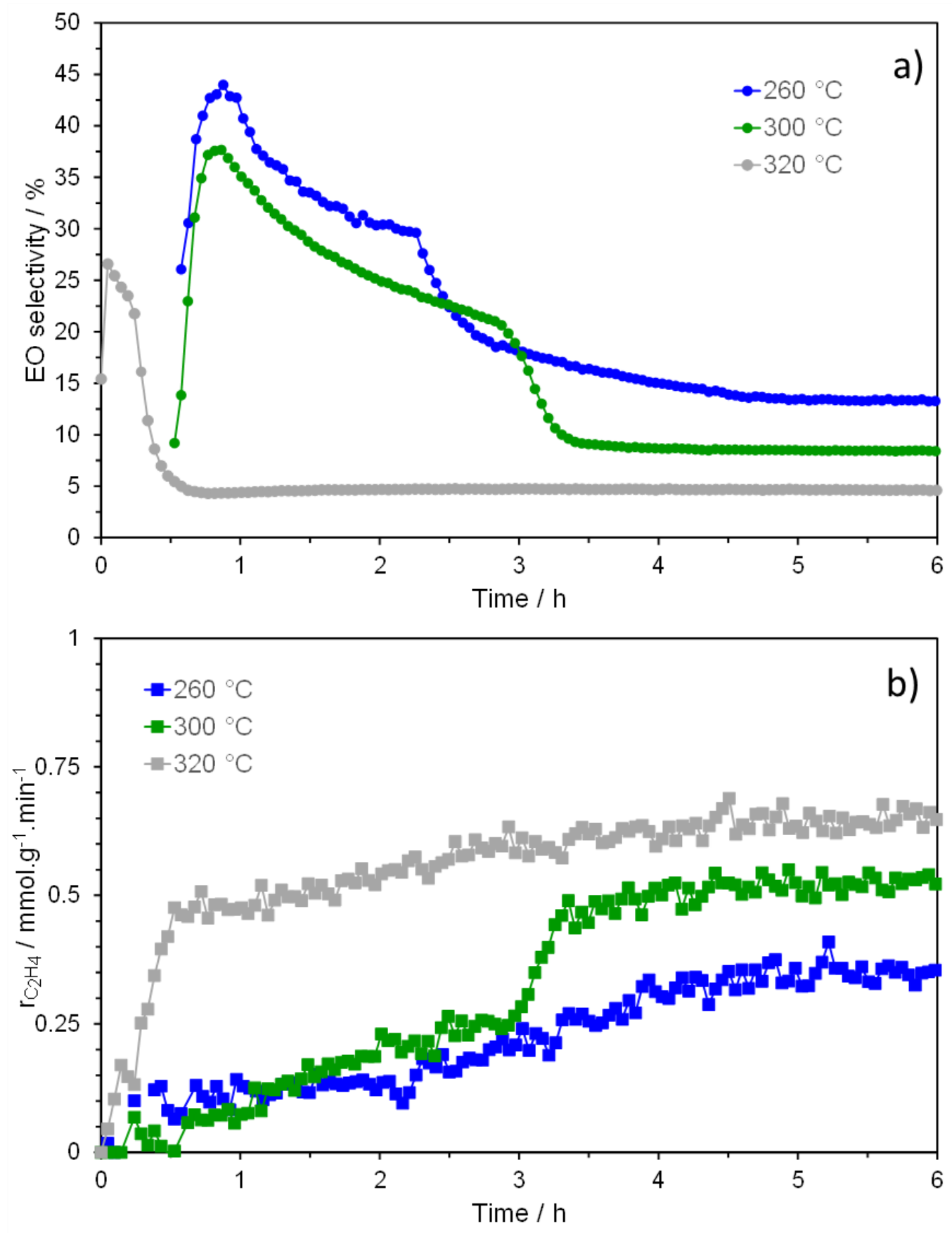

Figure 1: Time-variation of the catalytic properties of the planar Ag/YSZ cermet coatings in ethylene rich conditions: a) EO selectivity and b) intrinsic catalytic rate of ethylene consumption expressed per g of Ag. 


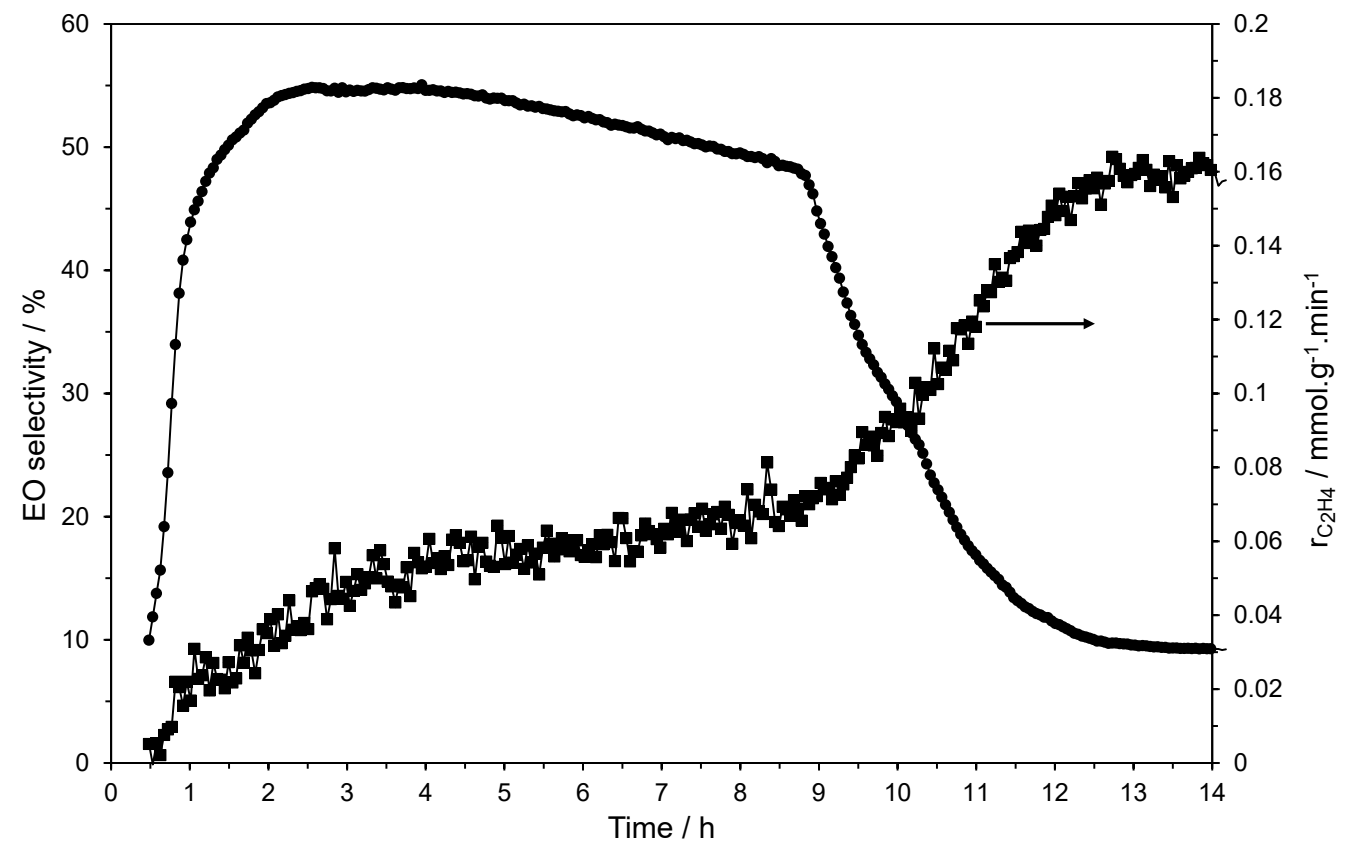

Figure 2: Time evolution of the EO selectivity and the intrinsic ethylene consumption rate (expressed per $\mathrm{g}$ of $\mathrm{Ag}$ ) of the tubular $\mathrm{Ag} / \mathrm{YSZ}$ cell. Reaction conditions: $3.8 \% \mathrm{C}_{2} \mathrm{H}_{4}, 1.1 \% \mathrm{O}_{2}$ (He balance, $3 \mathrm{~L} \mathrm{~h}^{-1}$ ). Temperature: $300^{\circ} \mathrm{C}$. 


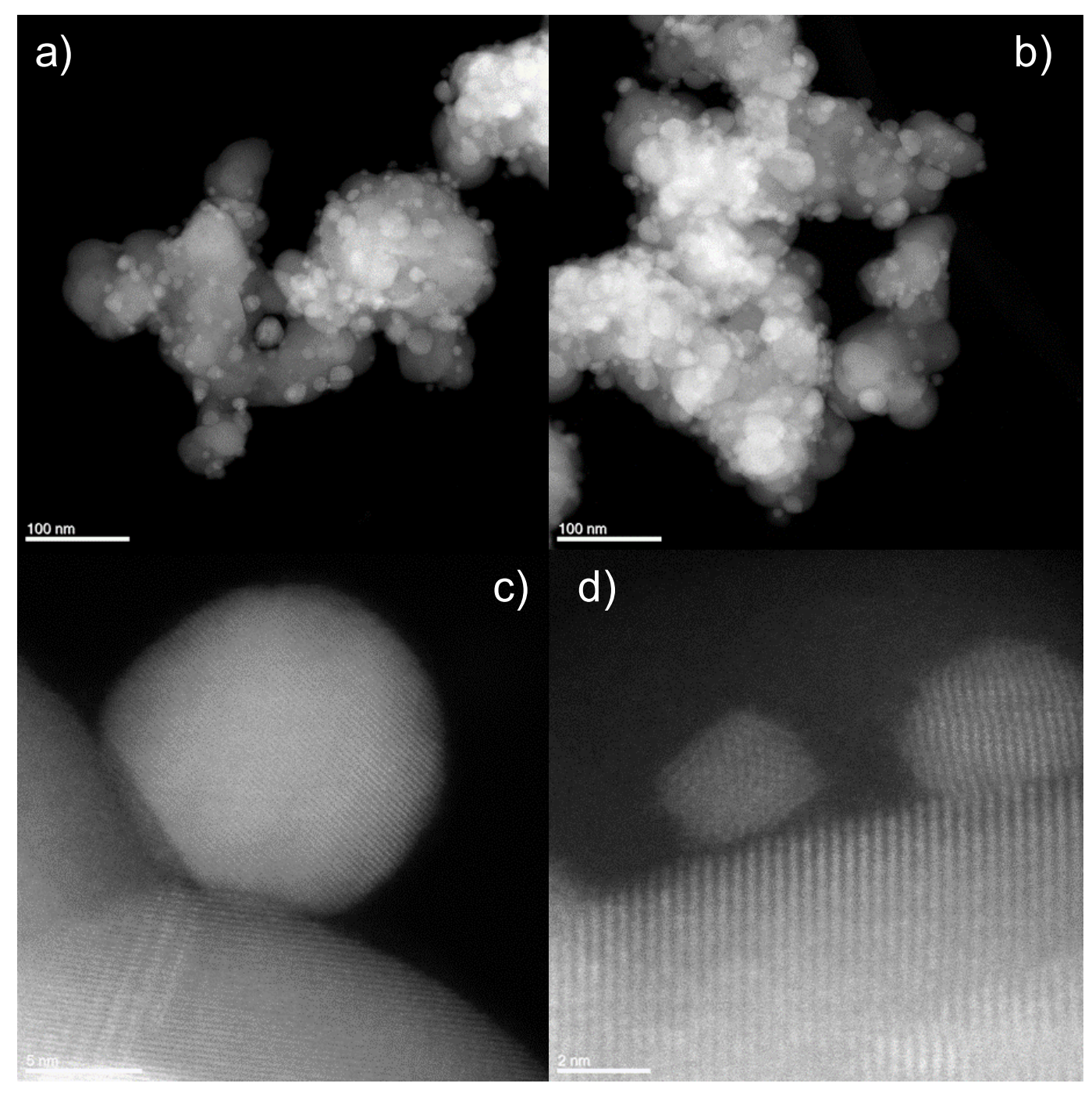

Figure 3: Representative ex-situ STEM images of the Ag/YSZ cermet coating in the intermediate "selective" state. The sample was subjected to ethylene epoxidation reaction conditions $(3.8 \%$ $\mathrm{C}_{2} \mathrm{H}_{4}+1.1 \% \mathrm{O}_{2}$, He balance, $3 \mathrm{~L} \mathrm{~h}^{-1}$, Temperature $=300^{\circ} \mathrm{C}$ ) for $45 \mathrm{~min}$, and then cooled down in He.

In-situ TEM experiments were performed to observe the $\mathrm{Ag} / \mathrm{YSZ}$ cermet coatings at $300^{\circ} \mathrm{C}$ in the reactive mixture (Total pressure: 4 mbar). Figure 4 shows a selection of in-situ TEM images obtained at different times under the ethylene epoxidation reaction atmosphere. A full accelerated 
video (video S1) is shown in the supporting information. We selected a catalyst zone where some YSZ crystallites can be easily observed and near micrometric Ag agglomerates (Fig. S5). No significant modification of the catalyst was observed after $17.5 \mathrm{~min}$ in the reactive atmosphere, in good agreement with the induction time (Figs 1 and 2) required to activate the catalyst. However, isolated Ag clusters (white circles such as at top right) can already be observed on the carbon film (covering the microscopy copper grid) near a YSZ crystallite. After 21.5 min on stream (Fig. 4b), small Ag clusters now appear on the surface of YSZ crystallites (white arrows) and are more numerous on the carbon film (white circles). Figs. 4c-f highlight the in-situ formation of new Ag clusters, their coalescence and growing with time. For instance, the isolate Ag cluster size on the carbon film (white circle at top right) increases from ca. 3-4 nm after 17:30 on stream up to around $15 \mathrm{~nm}$ at the end of the observation (after around $1.5 \mathrm{~h}$ ). Similar observations can be made on Ag clusters supported on YSZ such as the example of the arrow marked with a star. To confirm that these phenomena were not caused by the electron-beam, the sample was cooled down to room temperature under $\mathrm{N}_{2}$ after the in-situ experiment. Then, a different area of the sample, not previously exposed to the electron beam at $300^{\circ} \mathrm{C}$, was analyzed by TEM at room temperature (under vacuum, no gas). TEM images confirm the in-situ formation of small Ag nanoparticles (2$15 \mathrm{~nm}$ ) on YSZ (Fig. S6). These in-situ TEM study confirm that the time variation of the catalytic activity is linked to the operando formation, ripening and coalescence of Ag clusters on YSZ. This implies a self-redispersion of Ag from micrometric Ag agglomerates into small Ag clusters on YSZ. This phenomenon has been already observed during high-temperature thermal treatments in oxygen $\left(500-800^{\circ} \mathrm{C}\right)$ and used to re-disperse $\mathrm{Ag}$ on supports such as $\mathrm{CeO}_{2}$ [22], SBA-15 [23], antimony-doped tine oxide [24] and $\mathrm{Al}_{2} \mathrm{O}_{3}$ [25] to produce active catalysts for $\mathrm{CO}$ and soot oxidation. Volatile AgOx species produced at high temperatures in oxygen are trapped by defects on the supports such as oxygen vacancies which act as acceptors of $\mathrm{Ag}^{+}$ions. The surface of 
micrometric Ag agglomerates of $\mathrm{Ag} / \mathrm{YSZ}$ cermet was probably oxidized during the calcination step at $600^{\circ} \mathrm{C}$, forming volatile $\mathrm{AgOx}$ species which were trapped on surface oxygen vacancies of YSZ. Indeed, this oxide is well-known to contain oxygen vacancies to keep its electrical neutrality after the partial substitution of $\mathrm{Zr}^{4+}$ cations by $\mathrm{Y}^{3+}$ ones. In reducing conditions (ethylene rich conditions) at low temperatures $\left(260-320^{\circ} \mathrm{C}\right), \mathrm{Ag}^{+}$cations are reduced, rapidly diffuse and coalesce to first form small clusters and then larger Ag nanoparticles. Our results indicate that only small Ag clusters initially formed on YSZ are selective for epoxidation as observed during the intermediate "selective" state (Figs. 1 and 2). This assumption is corroborated by similar results obtained on propylene epoxidation [26]. Nevertheless, the sintering process of these small Ag clusters is too fast even at $260^{\circ} \mathrm{C}$ to keep selective $\mathrm{Ag}$ species on YSZ.

Positive currents $(+500 \mu \mathrm{A})$ were applied at $300^{\circ} \mathrm{C}$ in ethylene rich condition to supply electrophilic oxygen species onto the $\mathrm{Ag} / \mathrm{YSZ}$ cermet. However, we did not observe any impact on the catalytic properties most probably because active Ag nanoparticles supported on insulating YSZ grains were not affected by the current.

This finding of the oxidation/evaporation/trapping/diffusion process could be further applied to prepare $\mathrm{Ag} /$ oxide catalysts with highly dispersed Ag clusters on the oxide. A short reduction phase at low temperature (probably lower than $100^{\circ} \mathrm{C}$ ) after an initial high temperature calcination step could produce highly efficient $\mathrm{Ag} / \mathrm{oxide}$ catalysts and electrocatalysts for applications in oxidizing conditions for avoiding the fast sintering process.

To go further, we decided to prepare a Ag/GDC cermet as GDC is a MIEC, able to transport both electrons and oxygen ions even at low temperatures. Therefore, Ag clusters on GDC will be affected by the polarization of the cermet. In addition, the ionic conductivity of GDC is a least 10 times higher than that $\mathrm{YSZ}$ below $400^{\circ} \mathrm{C}$ [17]. For instance, the catalytic activity for propene 
oxidation of a Pt film deposited on a GDC dense membrane was electropromoted at $190{ }^{\circ} \mathrm{C}$ upon the application of a positive current of $+500 \mu \mathrm{A}$ [27]. Furthermore, the electronic conductivity of GDC is enhanced by a reducing atmosphere, as the ethylene epoxidation one, due to the partial reduction of $\mathrm{Ce}^{4+}$ into $\mathrm{Ce}^{3+}$.

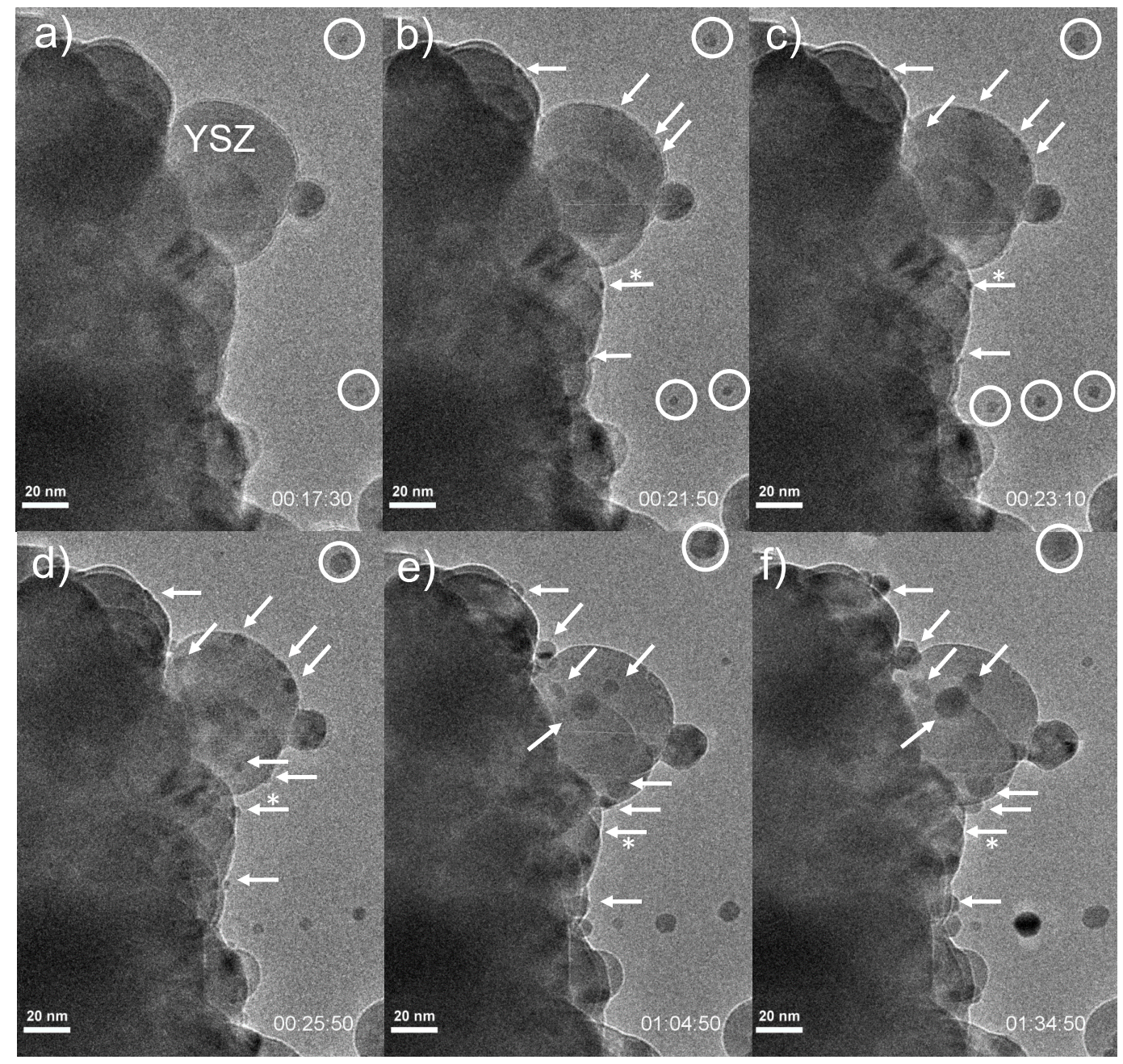

Figure 4: (a-f) in-situ TEM images of the evolution of Ag/YSZ cermet layer under ethylene epoxidation reaction conditions at different times (specified in each image in hh.mm.ss). Reaction conditions: $3.8 \% \mathrm{C}_{2} \mathrm{H}_{4}+1.1 \% \mathrm{O}_{2}(4 \mathrm{mbar})$. Temperature: $300^{\circ} \mathrm{C}$. (circle: isolated $\mathrm{Ag}$ cluster; arrow: Ag cluster apparition on YSZ). 


\subsection{Characterizations of Ag/GDC cermet coatings}

We used the reactive magnetron sputtering method to optimize the nanostructure of $\mathrm{Ag} / \mathrm{GDC}$ cermet. The X-ray diffractogram of the as-grown state on silicon substrate (Fig. S2b) is strongly dominated by $\mathrm{Ag}_{2} \mathrm{CO}_{3}$ contributions. We decided to anneal the films in air at $350{ }^{\circ} \mathrm{C}$ for $2 \mathrm{~h}$ to trigger the thermal decomposition of $\mathrm{Ag}_{2} \mathrm{CO}_{3}$ [28] and the formation of crystalline metallic silver with fec structure. In addition, small (111), (200) and (220) peaks, consistent with GDC, confirm the crystallization of the ionic conductor. The porosity of $\mathrm{Ag} / \mathrm{GDC}$ cermet coatings increases substantially during the annealing treatment (Figs. S2c and d). This was confirmed by in-situ observation of the catalyst surface by environmental scanning electron microscopy during a thermal ramp from room temperature to $350^{\circ} \mathrm{C}$, followed by a $2 \mathrm{~h}$ plateau at $350^{\circ} \mathrm{C}$ under $120 \mathrm{~Pa}$ of air (video S2). Considering the molar volume of $\mathrm{Ag}_{2} \mathrm{CO}_{3}$ and $\mathrm{Ag}^{0}\left(22,68\right.$ and 10,28 $\mathrm{cm}^{3} / \mathrm{Ag}$, respectively), the thermal decomposition of $\mathrm{Ag}_{2} \mathrm{CO}_{3}$ can explain the observed structural opening of the catalytic coatings. This is supported by the cross-section SEM image (Fig. S2e) taken in Backscattered-Electron (BSE) mode which evidences metallic silver nanoparticles (observed bright spots) and a coatings thickness of ca. $1450 \mathrm{~nm}$. Furthermore, SIMS analysis (Fig. S7) highlights that the intensities of metallic elements constituting the film are of the same order of magnitude before and after annealing. On the other hand, those of carbon and oxygen drop by one order of magnitude. XPS analysis of the electronic structure at the C-1s and Ag-3d core levels (Fig. S8, Tables S1 and S2) indicate that nearly $30 \%$ of surface carbon atoms are involved in $\mathrm{CO}_{3}{ }^{2-}$ species and ca. $47 \%$ of silver atoms are of $\mathrm{Ag}(\mathrm{I})$ state such as in $\mathrm{Ag}_{2} \mathrm{CO}_{3}$ before annealing. On the other hand, after annealing, only $6 \%$ of surface carbon atoms are involved in $\mathrm{CO}_{3}{ }^{2-}$ species and only $\operatorname{Ag}(0)$ can be detected, confirming the presence of metallic Ag nanoparticles. 
We have measured the sheath resistance of the $\mathrm{Ag} / \mathrm{GDC}$ cermet coating of $544000 \Omega / \square$ at room temperature before annealing. This sheath resistance dropped after annealing to a value of $62 \Omega / \square$, corresponding to a low resistivity of $7,38.10^{-3} \Omega . \mathrm{cm}$. This indicates that the Ag network percolated in the whole volume of the coating to ensure a good electronic conductivity. Therefore, the $\mathrm{Ag} / \mathrm{GDC}$ cermet coating after calcination at $350^{\circ} \mathrm{C}$ is highly porous and electronic conductor.

\subsection{Electrocatalytic activity of Ag/GDC cermet coatings.}

The catalytic activity of Ag/GDC cermet coatings for the ethylene epoxidation was investigated at atmospheric pressure at three constant temperatures: 220,250 and $300{ }^{\circ} \mathrm{C}$ and for two reactive mixtures, i.e., ethylene rich $\left(\mathrm{O}_{2} / \mathrm{C}_{2} \mathrm{H}_{4}=0.29\right)$ and oxygen rich $\left(\mathrm{O}_{2} / \mathrm{C}_{2} \mathrm{H}_{4}=2\right)$. Prior to the electrocatalytic experiments, the catalytic performances were stabilized in the ethylene rich reactive mixture at $300^{\circ} \mathrm{C}$ for $43 \mathrm{~h}$. During this activation period, the ethylene conversion gradually increased from 0.3 up to $1.8 \%$ while the EO selectivity reaches a steady-state at around $8 \%$ after $20 \mathrm{~h}$ on stream. It is worth noting that, contrary to Ag/YSZ cermet, no intermediate "selective" state was observed on $\mathrm{Ag} / \mathrm{GDC}$ cermet coatings. This is due to the low temperature of the calcination step $\left(350^{\circ} \mathrm{C}\right)$, which is too low for $\mathrm{AgOx}$ species evaporation. After $43 \mathrm{~h}$ on stream, the intrinsic ethylene consumption rate reached a stable value at $4.73 \mathrm{mmol} \mathrm{g}^{-1} \mathrm{Ag} \mathrm{min}^{-1}$, which is ca. 8 times higher than the best activity of a $\mathrm{Ag} / \mathrm{YSZ}$ cermet layer (Fig. 1).

Fig. 5 displays a typical experiment performed at $220{ }^{\circ} \mathrm{C}$, showing that small positive currents (from 100 up to $800 \mu \mathrm{A}$ ) abruptly and reversibly enhance the selectivity towards EO and the overall catalytic rate of ethylene consumption. These two parameters, as well as the cell voltage ( $\left.\Delta \mathrm{V}_{\mathrm{WCE}}\right)$, rapidly reach a steady-state value during the $1 \mathrm{~h}$ applied current plateau. Furthermore, the magnitude of the activation gradually increases with the intensity of the current. This demonstrates 
that small applied currents can promote both the ethylene conversion and the EO selectivity. For instance, upon the application of $+800 \mu \mathrm{A}$, the catalytic rate increases by $15 \%$ while the EO selectivity raises from $16.5 \%$ at OCV up to $19.5 \%$. It is worth noting that these levels of EO selectivity are rather low, which is probably due to the fact that these experiments were performed at atmospheric pressure, in contrast with 10-30 bars commonly used for industrial catalysts. In addition, ceria-based supports such as GDC are active for the undesired combustion reactions [29]. Therefore, a part of the electrochemically produced EO is most probably consecutively oxidize to $\mathrm{CO}_{2}$, then lowering the magnitude of the electrocatalytic activation. Furthermore, the catalytic activity of the nanostructured Ag/GDC coating is rather high, since the intrinsic ethylene consumption rates calculated per gram of $\mathrm{Ag}$ are in the range $0.7-2.5 \mathrm{mmol} \mathrm{g}^{-1} \mathrm{~min}^{-1}$ at 220 $250^{\circ} \mathrm{C}$ (Fig. 5b and $\mathrm{S} 9 \mathrm{~b}$ ) while much lower values $\left(\approx 10^{-3} \mathrm{mmol} \mathrm{g}^{-1} \mathrm{~min}^{-1}\right)$ [30] are reported in literature at $237^{\circ} \mathrm{C}$ on $\mathrm{Ag}$-supported $\alpha-\mathrm{Al}_{2} \mathrm{O}_{3}$ catalysts. Fig. S9 gives an overview of the impact of the applied currents under different temperatures and reactive mixtures. Whatever the temperature and the $\mathrm{O}_{2} / \mathrm{C}_{2} \mathrm{H}_{4}$ ratios, positive currents enhance both the EO selectivity and the ethylene consumption rate. On the contrary, negative currents have no effect on the catalytic properties. 

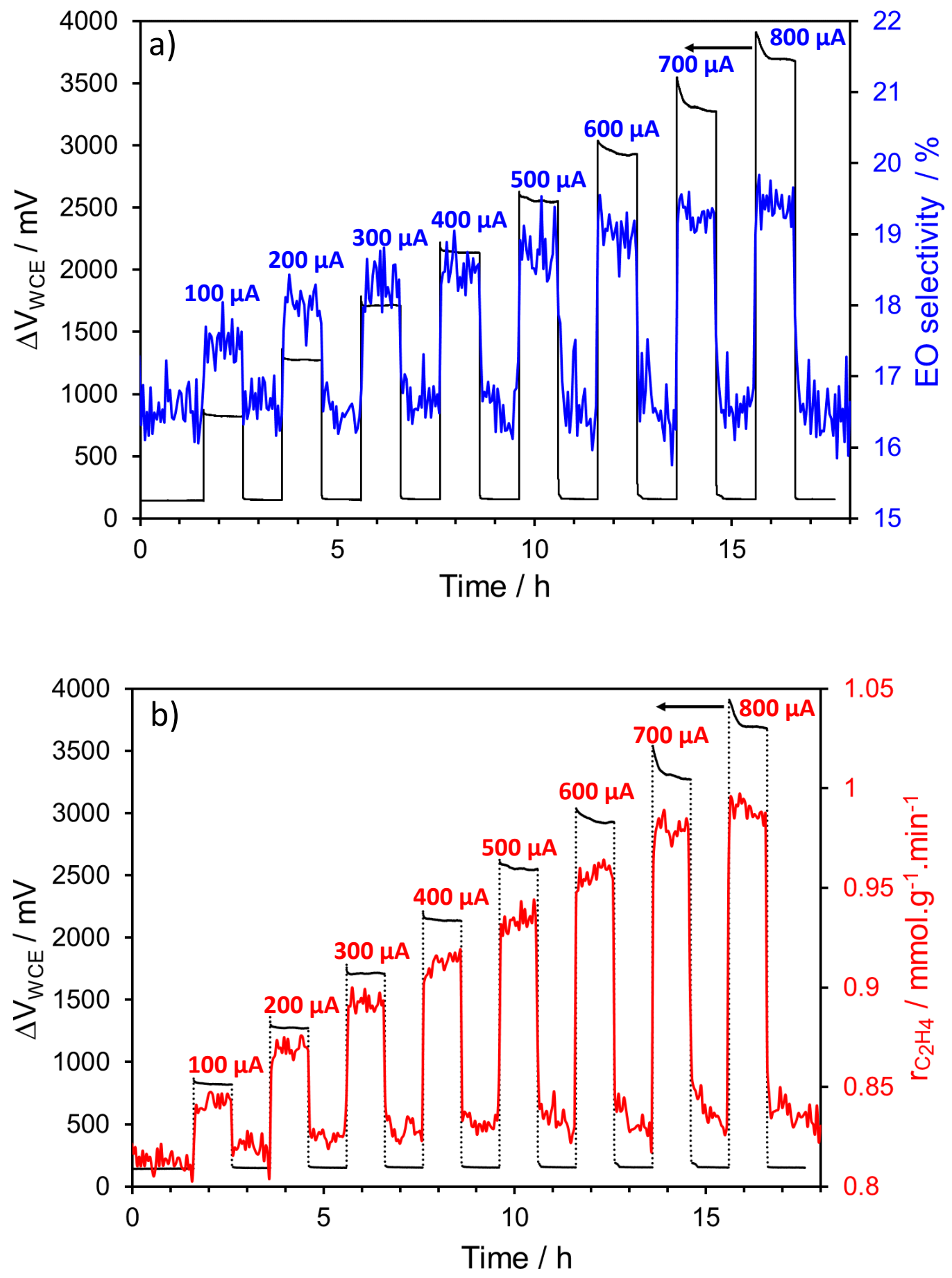

Figure 5: Impact of the applied currents on the catalytic activity of the $\mathrm{Ag} / \mathrm{GDC}$ cermet coatings at $220^{\circ} \mathrm{C}$. (a) EO selectivity and (b) overall catalytic rate of ethylene consumption. Ethylene-rich reactive mixture: $3.8 \% \mathrm{C}_{2} \mathrm{H}_{4} / 1.1 \% \mathrm{O}_{2}$. 
We have calculated the gain in EO selectivity (eq. 1) and in ethylene consumption rate (eq. 2) as a function of the applied current (Figs. 6 and S10). For ethylene-rich conditions, the EO selectivity gain increases with the current and is clearly temperature dependent, decreasing with the temperature. At $220{ }^{\circ} \mathrm{C}$, the $\mathrm{EO}$ selectivity gain is already significant upon $100 \mu \mathrm{A}(6.5 \%)$ and raises up to more than $18 \%$ for $800 \mu \mathrm{A}$ as does the ethylene consumption rate gain. In oxygen-rich conditions (Fig. S10), gains are smaller at $220^{\circ} \mathrm{C}$ most probably because the lower GDC electronic conductivity in oxidizing conditions inhibits the activation process.

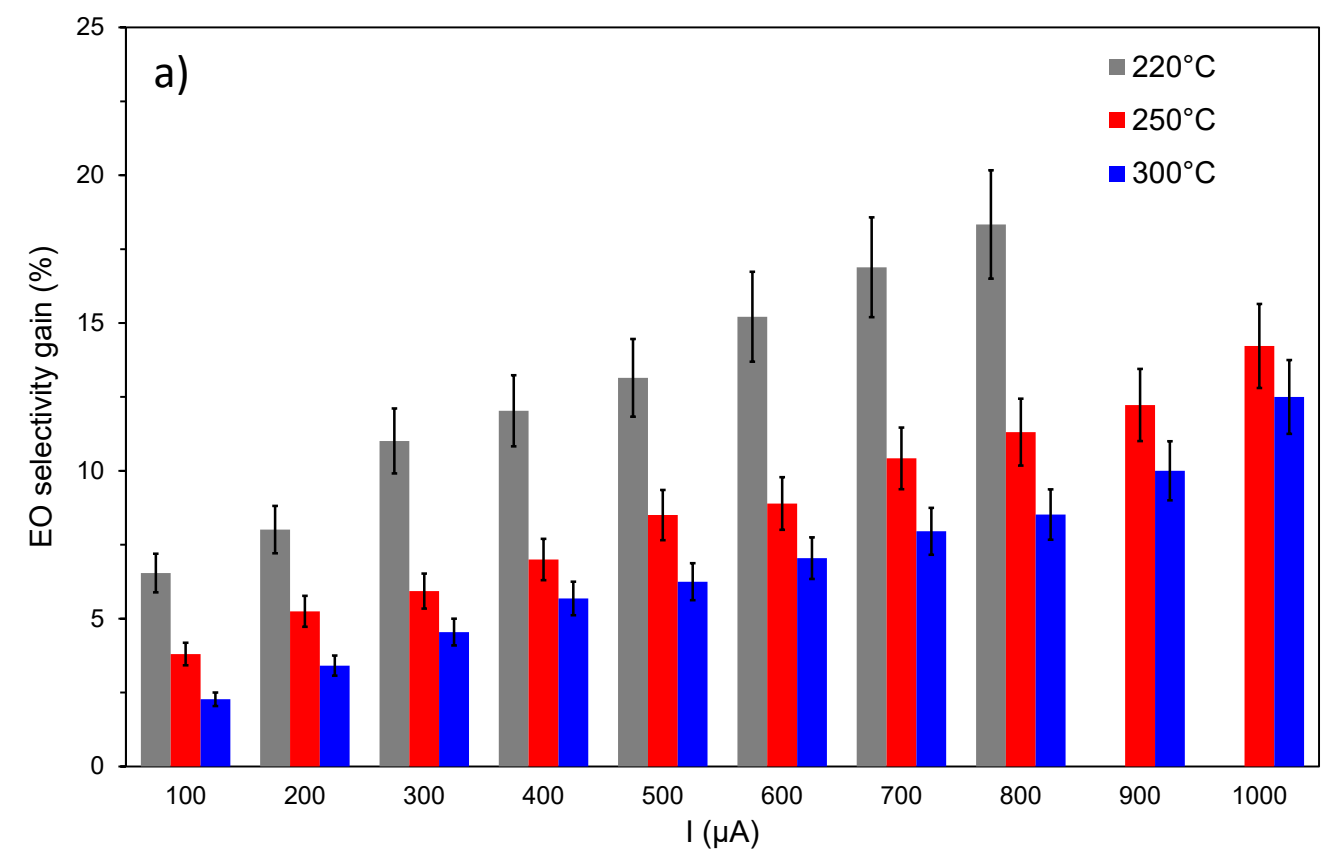




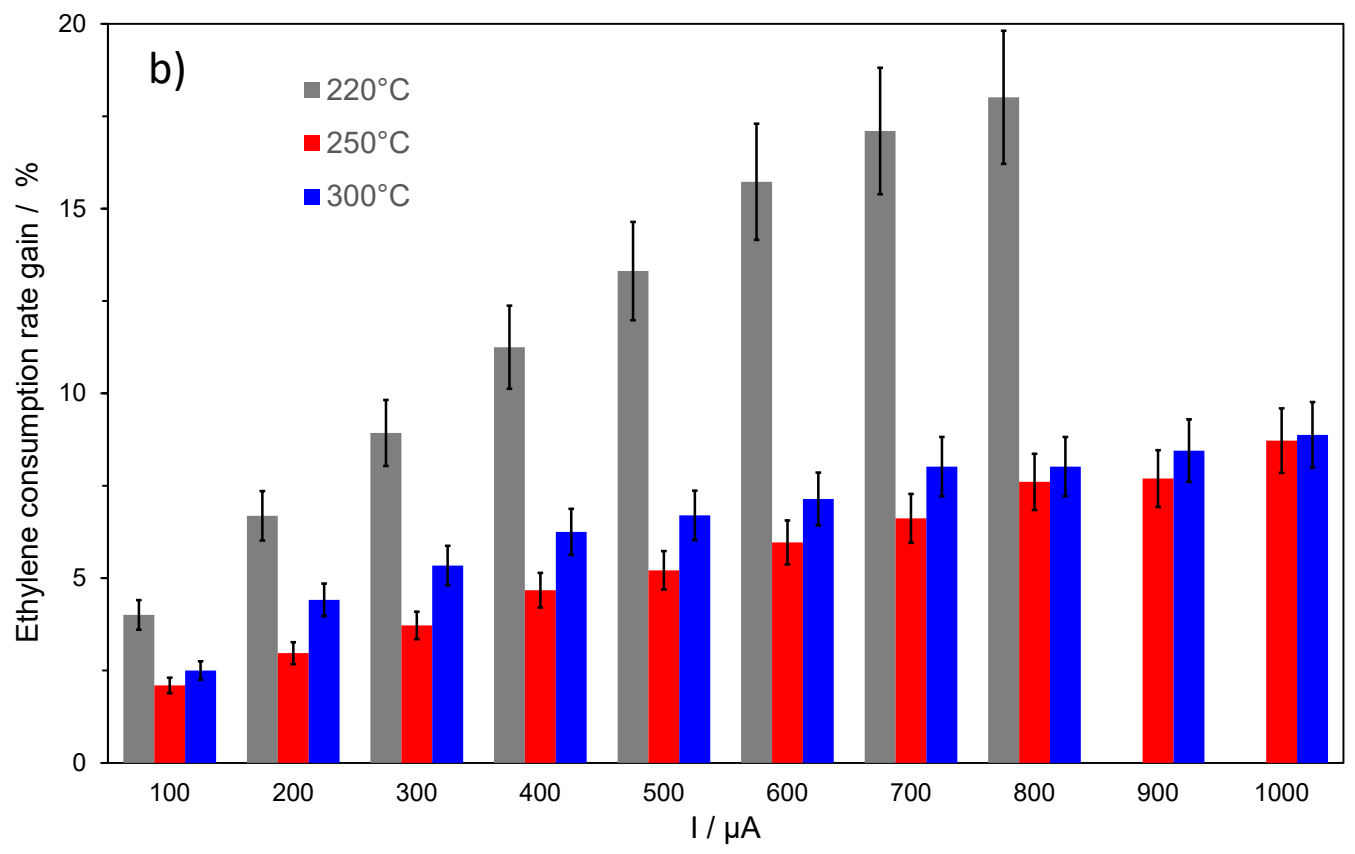

Figure 6: Impact of the applied current on a) the EO selectivity gain and b) on the ethylene consumption rate gain of the $\mathrm{Ag} / \mathrm{GDC}$ cermet coating in ethylene-rich conditions.

Whatever the temperature and the reactive mixture, the EO selectivity gain linearly increases with the intensity of the applied current (Fig. 7). We assume that the selectivity enhancement is linked to an electrochemical process involving the direct electrochemical oxidation of ethylene to EO (4), which competes with the electrochemical oxygen evolution reaction (5).

$$
\mathrm{O}^{2-}(\mathrm{GDC}) \rightarrow 1 / 2 \mathrm{O}_{2}(\mathrm{~g})+2 \mathrm{e}^{-}(\mathrm{Ag})
$$

The slopes, extracted from the linear curves (Fig. 7), with determination coefficients $\mathrm{R}^{2}$ larger than 0.95 , show that the linear enhancement of the selectivity at $220^{\circ} \mathrm{C}$ with the current is twice larger in the ethylene-rich conditions than that under the oxygen-rich ones (Table S3). On the other hand, at $250{ }^{\circ} \mathrm{C}$ and $300{ }^{\circ} \mathrm{C}$, slopes are rather similar whatever the reactive mixture and the temperature. This can be attributed to the kinetics of the competitive oxygen electrode reaction (5) on $\mathrm{Ag}^{0}$ which are known to increase with the temperature and the oxygen partial pressure [31]. In addition, the 
rate of the subsequent oxidation of EO into $\mathrm{CO}_{2}$ also increases with the temperature, lowering the positive impact of the current on the EO selectivity. The Faradaic efficiency corresponding to the EO production (FEEO, eq. 3) was found to be in the range 7-25\% (Fig. S11). Therefore, contrary to EPOC, the enhancement of the EO production rate is smaller than that predicted by the Faraday law. The observed promotional effects on the EO selectivity upon polarization is attributed to the direct electrochemical oxidation of ethylene into ethylene oxide (4). Electrophilic oxygen species directly react with ethylene to produce EO and are not spectator promoting agents as in case of EPOC processes. Only a small part of the applied current (7-25\%) is utilized to produce EO, the rest being used for the oxygen evolution. Nevertheless, a low FEEo value of around 7\% was sufficient to achieve the greatest EO selectivity gain of $+18 \%$ at $220{ }^{\circ} \mathrm{C}$ upon $+800 \mu \mathrm{A}$ in ethylene rich condition. These results highlight the potential for improvement of this new electrocatalytic route of EO production.

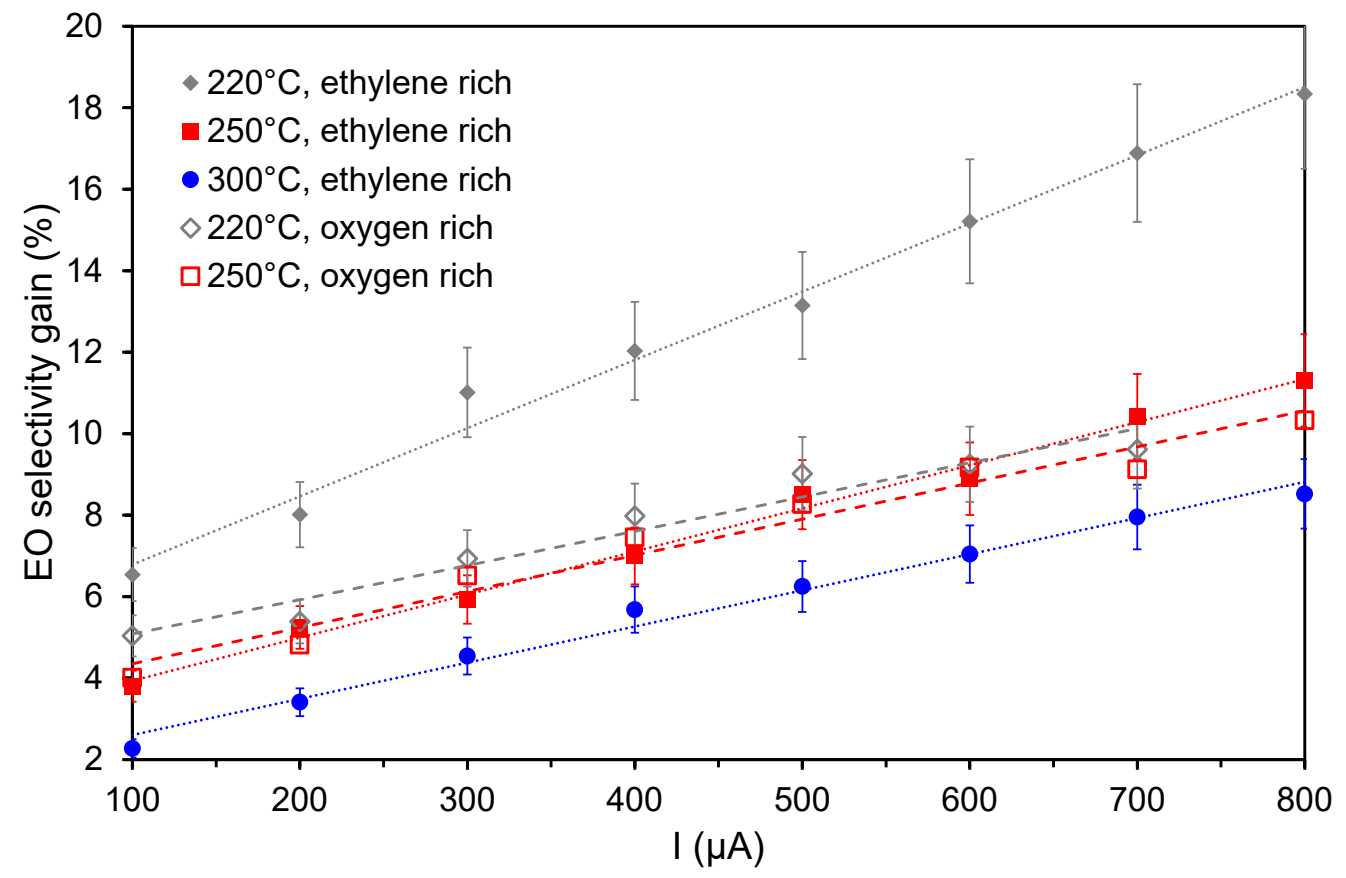

Figure 7: Linear relationship between the EO selectivity gain and the current intensity for the Ag/GDC cermet coating. 
To deeply characterize the nanostructure of the Ag/GDC cermet coating, a FIB lamella was extracted after the electrocatalytic tests and was observed by HR-STEM and HRTEM (Figs. 8 and S12). The catalytic coating nanostructure is composed of parallel nanofibers of diameter ranging between 40 and $100 \mathrm{~nm}$ and length of ca. $1 \mu \mathrm{m}$. Fig. 8a shows the $\mathrm{O}, \mathrm{Ag}$ and Ce composition mapping in the coating. The surface feature of the GDC membrane is visible underneath the film. Nanofibers are mainly composed of GDC partially covered by Ag. Fig. $8 \mathrm{~b}$ evidences that the space between parallel nanofibers $(20-70 \mathrm{~nm}$ width) is filled at the interface with the GDC substrate by Ag agglomerates which are connecting the nanofibers to each other. Furthermore, HR-TEM images evidence the presence of Ag nanoparticles (2-5 nm size) on the nanofibers surface. FFT diffraction patterns at the nanoscale (Fig. 8c) confirm the strong interaction of Ag nanoparticles and GDC. Large Ag domains connecting the nanofibers are certainly responsible for percolation of electrical paths enabling the electronic conductivity and the electrochemical reactions. This emphasizes the dual function of the $\mathrm{Ag} / \mathrm{GDC}$ cermet coating, able to combine high electrochemical and catalytic performances. Despite low values of Faradaic efficiencies, the EO selectivity and the ethylene conversion can be increased at $220{ }^{\circ} \mathrm{C}$ with the application of small positive currents that correspond to an energy consumption of around $\sim 1 \mathrm{~mW} / \mathrm{cm}^{2}$. This proof-of-concept opens the way for a new environmentally-friendly route (without utilization of chlorinated hydrocarbons) for the epoxidation of ethylene in a solid oxide cell via direct electrooxidation of ethylene. These results also underline the key role of $\mathrm{O}^{2-}$ species in the mechanism of ethylene epoxidation on Ag. However, many factors have to be optimized before considering an industrial application of this new concept. The first issue will be to optimize the composition of the Ag electrode in order to hinder or remove the combustion reactions. As already mentioned, ceria-based supports such as GDC (Gadolinia-Doped Ceria) are active for ethylene and EO deep oxidation [29]. GDC was used in this present study because this is the state-of-the-art mixed ionic and electronic conductor 
(MIEC) material in solid oxide electrochemical cells. However, an alternative MIEC material which is not an oxidizing agent has to be used to further improve the electrocatalytic process for EO production. The improvement of the electrode nanostructure is also crucial to enhance the Faradaic efficiency by hindering the direct electrochemical oxidation of $\mathrm{O}^{2-}$ into $\mathrm{O}_{2}$ at the triple phase boundaries. Key factors such as the length and diameter of the MIEC parallel nanofibers and the distance between them have to be tailored to find the best compromise. Furthermore, these factors also control the surface area of the electrode. For scaling-up the process, optimised nanostructured Ag-based electrodes could be implemented in commercial SOFC-type reactors. Long-term experiments coupled with characterizations have to be performed in these SOFC-type reactors to assess the durability of the Ag-based electrodes upon polarisation. Nevertheless, the Ag-based electrodes were annealed at $350^{\circ} \mathrm{C}$ for $2 \mathrm{~h}$ before electrocatalytic tests. This much higher temperature compared to that of the operation (typically $220^{\circ} \mathrm{C}$ ) suggests a good thermal stability of the electrodes. 

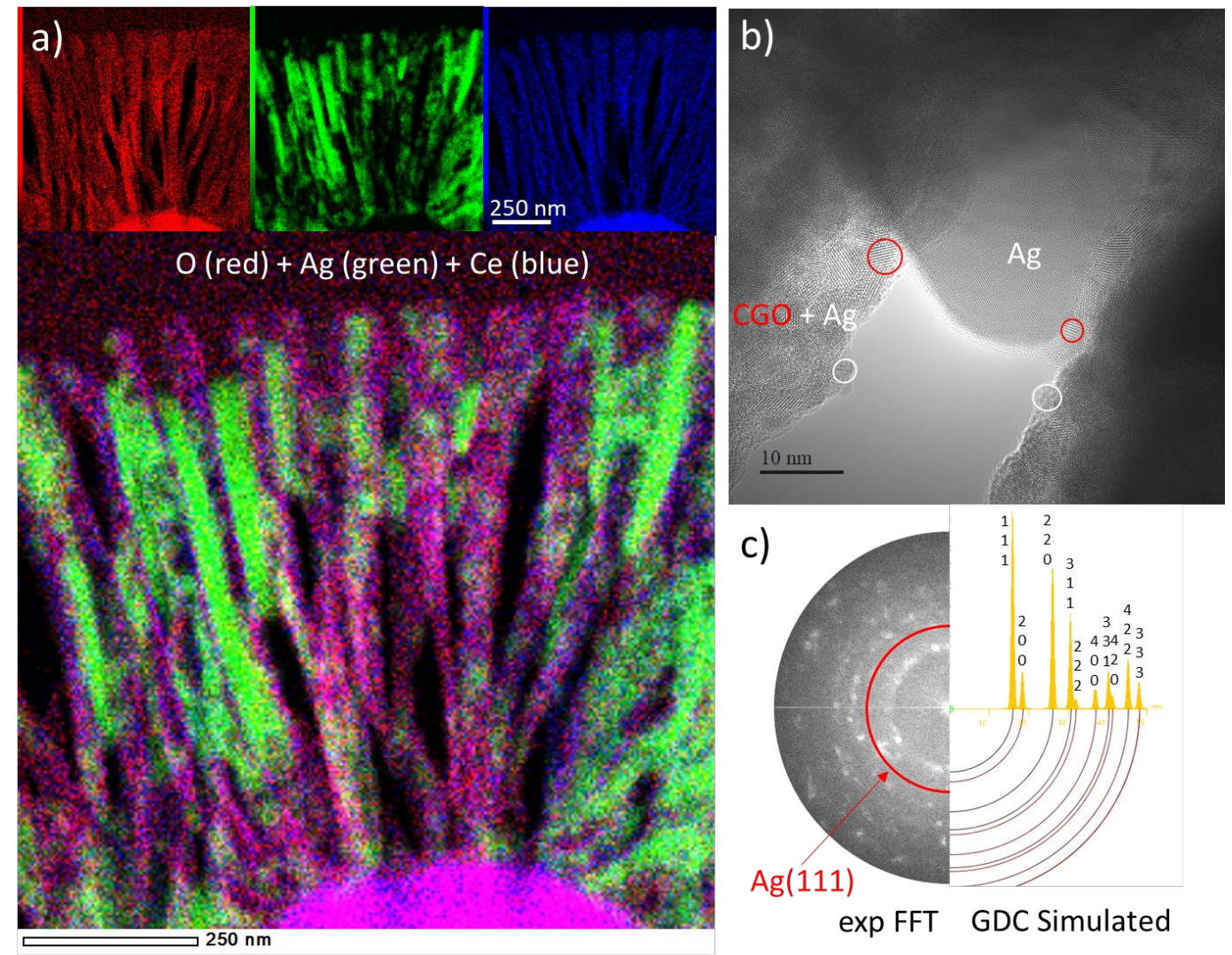

Figure 8: (a) O, Ag and Ce composition maps and composite map collected by HR-STEM of a Ag/GDC cermet coating deposited on a GDC pellet after electrocatalytic tests. (b) HRTEM image of the same film showing the local architecture inside and between two nanofibers (c) FFT of image b showing diffraction spots aligned on rings characteristic of crystalline fcc silver and fluorite GDC. Red circles : GDC and white circle : Ag nanoparticles.

\section{Conclusions}

We have investigated the catalytic activity for ethylene epoxidation at atmospheric pressure of $\mathrm{Ag} / \mathrm{YSZ}$ and Ag/GDC cermet coatings in solid oxide electrochemical cells. Environmental-TEM evidenced an operando self-redispersion of $\mathrm{Ag}$ in $\mathrm{Ag} / \mathrm{YSZ}$ cermet layers leading to the formation of small Ag clusters, selective for epoxidation, in close interaction with YSZ. However, the 
sintering process of these small $\mathrm{Ag}$ clusters is too fast even at $260^{\circ} \mathrm{C}$ to maintain the $\mathrm{EO}$ selectivity. Nevertheless, this finding, based on an oxidation/evaporation/trapping/diffusion process, could be further applied to prepare $\mathrm{Ag} /$ oxide catalysts and electrocatalysts with highly dispersed $\mathrm{Ag}$ clusters on the oxide. A short reduction phase at low temperature (probably lower than $100^{\circ} \mathrm{C}$ ) after the initial high temperature calcination step could produce efficient Ag/oxide electrocatalysts for applications only in oxidizing conditions to avoid the fast sintering process.

The reactive magnetron sputtering method was used to optimize the nanostructure of Ag/GDC cermet coated on GDC pellets. We found an unprecedent linear increase of the selectivity towards EO and of the ethylene conversion with the applied current, demonstrating for the first time the direct electrooxidation of ethylene into EO. Despite low values of Faradaic efficiencies, the EO selectivity and the ethylene conversion can be enhanced at $220{ }^{\circ} \mathrm{C}$ of around $18 \%$. This proof-ofconcept opens the way for a new environmentally-friendly route (without utilization of chlorinated hydrocarbons) for the epoxidation of ethylene in a solid oxide cell via direct electrooxidation of ethylene.

\section{Acknowledgments}

This study was performed in the "EPOX" project, funded by the French National Research Agency (ANR), ANR-2015-CE07-0026.

Supporting information. Figures S1 to S10. Tables S1 to S3. Video S1 and S2. Preparation and characterization of $\mathrm{Ag} / \mathrm{YSZ}$ and $\mathrm{Ag} / \mathrm{GDC}$ cermet coatings (SEM and TEM observations (ex-situ and in-situ), Experimental setup for reactive magnetron sputtering, Secondary ion mass spectrometry, X-ray photoelectron spectroscopy, HAADF microscopy). Electrocatalytic activity 
measurement of Ag/GDC coatings, Faradaic efficiencies and HAADF TEM observation after catalytic tests).

\section{References}

[1] M.O. Özbek, R.A. Van Santen, The mechanism of ethylene epoxidation catalysis, Catal. Letters. 143 (2013) 131-141. https://doi.org/10.1007/s10562-012-0957-3.

[2] A. Chongterdtoonskul, J.W. Schwank, S. Chavadej, Effects of oxide supports on ethylene epoxidation activity over Ag-based catalysts, J. Mol. Catal. A Chem. 358 (2012) 58-66. https://doi.org/10.1016/j.molcata.2012.02.011.

[3] T. Pu, H. Tian, M.E. Ford, S. Rangarajan, I.E. Wachs, Overview of Selective Oxidation of Ethylene to Ethylene Oxide by Ag Catalysts, ACS Catal. (2019) 10727-10750. https://doi.org/10.1021/acscatal.9b03443.

[4] Y.S. Yong, E.M. Kennedy, N.W. Cant, Oxide catalysed reactions of ethylene oxide under conditions relevant to ethylene epoxidation over supported silver, Appl. Catal. 76 (1991) 31-48. https://doi.org/10.1016/0166-9834(91)80003-F.

[5] J.K. Lee, X.E. Verykios, R. Pitchai, Support participation in chemistry of ethylene oxidation on silver catalysts, Appl. Catal. 44 (1988) 223-237. https://doi.org/10.1016/S0166-9834(00)80055-X.

[6] P. Christopher, S. Linic, Engineering selectivity in heterogeneous catalysis: Ag nanowires as selective ethylene epoxidation catalysts, J. Am. Chem. Soc. 130 (2008) 11264-11265. https://doi.org/10.1021/ja803818k.

[7] J.E. van den Reijen, S. Kanungo, T.A.J. Welling, M. Versluijs-Helder, T.A. Nijhuis, K.P. de Jong, P.E. de Jongh, Preparation and particle size effects of Ag/A-A12O3 catalysts for ethylene epoxidation, J. Catal. 356 (2017) 65-74. https://doi.org/10.1016/j.jcat.2017.10.001. 
[8] T.E. Jones, R. Wyrwich, S. Böcklein, E.A. Carbonio, M.T. Greiner, A.Y. Klyushin, W. Moritz, A. Locatelli, T.O. Menteş, M.A. Niño, A. Knop-Gericke, R. Schlögl, S. Günther, J. Wintterlin, S. Piccinin, The Selective Species in Ethylene Epoxidation on Silver, ACS Catal. 8 (2018) 3844-3852. https://doi.org/10.1021/acscatal.8b00660.

[9] P. Vernoux, L. Lizarraga, M.N. Tsampas, F.M. Sapountzi, A. De Lucas-Consuegra, J.-L. Valverde, S. Souentie, C.G. Vayenas, D. Tsiplakides, S. Balomenou, E.A. Baranova, Ionically conducting ceramics as active catalyst supports, Chem. Rev. 113 (2013). https://doi.org/10.1021/cr4000336.

[10] M. Stoukides, C.G. Vayenas, The effect of electrochemicam oxygen pumping on the rate and selectivity of ethylene epoxidation on polycristalline silver, J. Catal. 70 (1991) 137-146.

[11] C.G. Vayenas, S. Bebelis, S. Neophytides, Non-faradaic electrochemical modification of catalytic activity, J. Phys. Chem. 92 (1988) 5083-5085. https://doi.org/10.1021/j100329a007.

[12] S. Bebelis, C.G. Vayenas, Non-faradaic electrochemical modification of catalytic activity 6. Ethylene epoxidation on Ag deposited on stabilized ZrO2, J. Catal. 138 (1992) 588-610. https://doi.org/10.1016/0021-9517(92)90309-6.

[13] C. Karavasilis, S. Bebelis, C.G. Vayenas, Non-Faradaic Electrochemical Modification of Catalytic Activity, J. Catal. 160 (1996) 190-204. https://doi.org/10.1006/jcat.1996.0138.

[14] A. De Lucas-Consuegra, A. Caravaca, P.J. Martínez, J.L. Endrino, F. Dorado, J.L. Valverde, Development of a new electrochemical catalyst with an electrochemically assisted regeneration ability for $\mathrm{H} 2$ production at low temperatures, J. Catal. 274 (2010) 251-258. https://doi.org/10.1016/j.jcat.2010.07.007.

[15] M.N. Tsampas, F.M. Sapountzi, A. Boréave, P. Vernoux, Isotopical labeling mechanistic studies of electrochemical promotion of propane combustion on Pt/YSZ, Electrochem. Commun. 26 (2013). https://doi.org/10.1016/j.elecom.2012.09.043.

[16] D. Horwat, J.F. Pierson, A. Billard, Magnetron sputtering of NASICON (Na3Zr2Si2PO12) thin 
films. Part II: A novel approach, Surf. Coatings Technol. 201 (2007) 7060-7065. https://doi.org/10.1016/j.surfcoat.2007.01.016.

[17] V. V. Kharton, F.M.B. Marques, A. Atkinson, Transport properties of solid oxide electrolyte ceramics: A brief review, Solid State Ionics. $174 \quad$ (2004) 135-149. https://doi.org/10.1016/j.ssi.2004.06.015.

[18] P. Vernoux, F. Gaillard, L. Bultel, E. Siebert, M. Primet, Electrochemical promotion of propane and propene oxidation on Pt/YSZ, J. Catal. 208 (2002). https://doi.org/10.1006/jcat.2002.3573.

[19] X. Li, F. Gaillard, P. Vernoux, Investigations under real operating conditions of the electrochemical promotion by $\mathrm{O}<\mathrm{inf}>2</ \mathrm{inf}>$ temperature programmed desorption measurements, Top. Catal. 44 (2007). https://doi.org/10.1007/s11244-006-0131-5.

[20] I. Kalaitzidou, T. Cavoué, A. Boreave, L. Burel, F. Gaillard, L. Retailleau-Mevel, E.A. Baranova, M. Rieu, J.P. Viricelle, D. Horwat, P. Vernoux, Electrochemical promotion of propylene combustion on Ag catalytic coatings, Catal. Commun. 104 (2018). https://doi.org/10.1016/j.catcom.2017.10.005.

[21] A. Chongterdtoonskul, J.W. Schwank, S. Chavadej, Effects of oxide supports on ethylene epoxidation activity over Ag-based catalysts, J. Mol. Catal. A Chem. 358 (2012) 58-66. https://doi.org/10.1016/j.molcata.2012.02.011.

[22] K.I. Shimizu, H. Kawachi, S.I. Komai, K. Yoshida, Y. Sasaki, A. Satsuma, Carbon oxidation with Ag/ceria prepared by self-dispersion of Ag powder into nano-particles, Catal. Today. 175 (2011) 9399. https://doi.org/10.1016/j.cattod.2011.03.053.

[23] X. Zhang, Z. Qu, F. Yu, Y. Wang, High-temperature diffusion induced high activity of SBA-15 supported Ag particles for low temperature CO oxidation at room temperature, J. Catal. 297 (2013) 264-271. https://doi.org/10.1016/j.jcat.2012.10.019.

[24] Z. Huang, T. Ban, Y. Zhang, L. Wang, S. Guo, C.R. Chang, G. Jing, Boosting the thermal stability and catalytic performance by confining Ag single atom sites over antimony-doped tin oxide via atom 
trapping, Appl. Catal. B Environ. 283 (2021) 119625. https://doi.org/10.1016/j.apcatb.2020.119625.

[25] H. Wang, S. Luo, X. Li, W. Liu, X. Wu, D. Weng, S. Liu, Thermally stable Ag/Al 2 O 3 confined catalysts with high diffusion-induced oxidation activity, Catal. Today. 332 (2019) 189-194. https://doi.org/10.1016/j.cattod.2018.06.027.

[26] Y. Lei, F. Mehmood, S. Lee, J. Greeley, B. Lee, S. Seifert, R.E. Winans, J.W. Elam, R.J. Meyer, P.C. Redfern, D. Teschner, R. Schlögl, M.J. Pellin, L.A. Curtis, S. Vajda, Increased Silver Activity for Direct Propylene Epoxidation via Subnanometer Size Effects, Science. 328 (2010) 224-228.

[27] R. Karoum, V. Roche, C. Pirovano, R.N. Vannier, A. Billard, P. Vernoux, CGO-based electrochemical catalysts for low temperature combustion of propene, J. Appl. Electrochem. 40 (2010) 1867-1873. https://doi.org/10.1007/s10800-010-0156-0.

[28] G.D. Nagy, J.B. Vergette, J.P. Connolly, Differential Thermal Analysis Studies on Ag 2 CO 3 , Can. J. Chem. 49 (1971) 3986-3993. https://doi.org/10.1139/v71-665.

[29] S. Rojluechai, S. Chavadej, J.W. Schwank, V. Meeyoo, Catalytic activity of ethylene oxidation over $\mathrm{Au}, \mathrm{Ag}$ and Au-Ag catalysts: Support effect, Catal. Commun. 8 (2007) 57-64. https://doi.org/10.1016/j.catcom.2006.05.029.

[30] P. Christopher, S. Linic, Shape- and size-specific chemistry of Ag nanostructures in catalytic ethylene epoxidation, ChemCatChem. 2 (2010) 78-83. https://doi.org/10.1002/cctc.200900231.

[31] T. Cavoué, A. Caravaca, I. Kalaitzidou, F. Gaillard, M. Rieu, J.P. Viricelle, P. Vernoux, Ethylene epoxidation on Ag/YSZ electrochemical catalysts: Understanding of oxygen electrode reactions, Electrochem. Commun. 105 (2019) 106495. https://doi.org/10.1016/j.elecom.2019.106495. 


\section{Figure captions}

Figure 1: Time-variation of the catalytic properties of the planar Ag/YSZ cermet coatings in ethylene rich conditions: a) EO selectivity and b) intrinsic catalytic rate of ethylene consumption expressed per $\mathrm{g}$ of $\mathrm{Ag}$.

Figure 2: Time evolution of the EO selectivity and the intrinsic ethylene consumption rate (expressed per $\mathrm{g}$ of $\mathrm{Ag}$ ) of the tubular $\mathrm{Ag} / \mathrm{YSZ}$ cell. Reaction conditions: $3.8 \% \mathrm{C}_{2} \mathrm{H}_{4}, 1.1 \% \mathrm{O}_{2}$ (He balance, $3 \mathrm{~L} \mathrm{~h}^{-1}$ ). Temperature: $300^{\circ} \mathrm{C}$.

Figure 3: Representative ex-situ STEM images of the Ag/YSZ cermet coating in the intermediate "selective" state. The sample was subjected to ethylene epoxidation reaction conditions $(3.8 \%$ $\mathrm{C}_{2} \mathrm{H}_{4}+1.1 \% \mathrm{O}_{2}$, He balance, $3 \mathrm{~L} \mathrm{~h}^{-1}$, Temperature $=300^{\circ} \mathrm{C}$ ) for $45 \mathrm{~min}$, and then cooled down in He.

Figure 4: (a-f) in-situ TEM images of the evolution of Ag/YSZ cermet layer under ethylene epoxidation reaction conditions at different times (specified in each image in hh.mm.ss). Reaction conditions: $3.8 \% \mathrm{C}_{2} \mathrm{H}_{4}+1.1 \% \mathrm{O}_{2}(4 \mathrm{mbar})$. Temperature: $300^{\circ} \mathrm{C}$. (circle: isolated $\mathrm{Ag}$ cluster; arrow: Ag cluster apparition on YSZ).

Figure 5: Impact of the applied currents on the catalytic activity of the Ag/GDC cermet coatings at $220^{\circ} \mathrm{C}$. (a) EO selectivity and (b) overall catalytic rate of ethylene consumption. Ethylene-rich reactive mixture: $3.8 \% \mathrm{C}_{2} \mathrm{H}_{4} / 1.1 \% \mathrm{O}_{2}$.

Figure 6: Impact of the applied current on a) the EO selectivity gain and b) on the ethylene consumption rate gain of the $\mathrm{Ag} / \mathrm{GDC}$ cermet coating in ethylene-rich conditions. 
Figure 7: Linear relationship between the EO selectivity gain and the current intensity for the $\mathrm{Ag} / \mathrm{GDC}$ cermet coating.

Figure 8: (a) O, Ag and Ce composition maps and composite map collected by HR-STEM of a Ag/GDC cermet coating deposited on a GDC pellet after electrocatalytic tests. (b) HRTEM image of the same film showing the local architecture inside and between two nanofibers (c) FFT of image b showing diffraction spots aligned on rings characteristic of crystalline fcc silver and fluorite GDC. Red circles : GDC and white circle : Ag nanoparticles. 